\title{
The Storrs Lectures: The Age of Anxiety
}

\author{
Grant Gilmore ${ }^{\dagger}$
}

\section{Editors' Introduction}

On three October afternoons last fall, we attended a presentation of the Storrs Lectures, entitled "The Ages of American Law." The William Lucius Storrs Lectureship was endowed in 1889 by Mary and Eliza Robinson, in memory of their great-uncle, the Chief Justice of the Connecticut Supreme Court.a The first lecture was given the following year by Judge Cooley on the Interstate Commerce Commission; he had just been appointed its first Chairman. The Storrs Lectures have remained the Law School's most distinguished lecture series; even a partial list includes some of the most influential legal figures and ideas of the past 85 years.b Sometimes annually, sometimes not, a speaker from outside the Law School is invited. This year the Lectures coincided with the Sesquicentennial of the Law School, and Grant Gilmorec had promised to deliver them.

Professor Gilmore is one of the most respected and best liked of a popular and respected faculty. ${ }^{d}$ Yet, so far as we know, he has never said a personal word, of any kind, to any student; indeed very different kinds of students claim him as their own, speculating on opinions never glimpsed beneath a deeply mannered ambivalence.

About 5'10", with a ruddy complexion and two pairs of frequently exchanged, thick-lensed glasses, Professor Gilmore has a somewhat stout, Tenniel-drawn physique. As he talks he emphasizes words through sudden and arresting changes in the clipped rumble and volume of his voice, like Theodore Roosevelt in the old reels appearing to speak through clenched teeth beneath a bristling mustache. As he raps an open book with his glasses or chops the air in casual impatience, his gestures remind us of someone thinking alone, trying to recall a familiar address or telephone number. Former lecturer in French at Yale College, Reporter for Article 9

$\dagger$ Sterling Professor of Law, Yale University.

a. See E. Forgeus, The History of the Storrs Lectureship in the Yale Law School 1 (1940).

b. Among the more prominent Storrs lecturers were: James Bradley Thayer (on the Law of Evidence); John Marshall Harlan (on the Constitution); Kazuo Hatoyama (on the Civil Code of Japan); Sir Frederick Pollock ("The Expansion of the Common Law"); Carl Becker ("The Heavenly City of the 18th Century Philosophers"); Edward Corwin ("The Twilight of the Supreme Court: A History of Our Constitutional Theory"); Robert Hutchins ("The Higher Learning in America"); Roscoe Pound ("An Introduction to the Philosophy of Law"); Karl Llewellyn ("The Common Law Tradition"); and, the most famous, Benjamin Nathan Cardozo's 1921 lectures, "On the Nature of the Judicial Process."

c. Professor Gilmore's brief hiatus at the University of Chicago Law School (1965-1973) made it possible for this confirmed Yale man (A.B. '31; Ph.D. '36; LL.B. '42; Professor since '46) to be invited.

d. Of some of Professor Gilmore's predecessors it was written,

They taught classes because their contracts with the University required them to do so; being conscientious craftsmen they worked hard on their classes; they were entirely indifferent to what their students thought about them or about their teaching; they did not ask to be loved.

(Written of Corbin, Moore and Sturges; manuscript on file at the Yale Law Journal.) 
of the UCC, coauthor of the standard treatise in Admiralty, Ames Prize and Coif Award winner, Gilmore seems to us, more than the Great Man, the Solitary. We anxiously awaited the lectures, entitled "The Age of Discovery," "The Age of Faith," "The Age of Anxiety."

On the afternoon of the 29th we arrived early and took seats near the front of the long room. The room quickly filled and the Dean introduced Professor Gilmore with a touching, if hurried pride. Gilmore seemed distracted; he wore an uncomfortably new white shirt with corners still stiff at the back of the collar. He began:

We are asked to believe that this year marks the hundred and fiftieth anniversary of the founding of this Law School. If that is true, the history of the School very nearly spans the history of American law. It seems appropriate, therefore, to devote these lectures to a review of the century and a half during which the Yale Law School and the American legal system have, at times somewhat uneasily, co-existed.

We sat next to Professor Deutsch and his wife, who had been Gilmore's research assistant for the preparation of his treatise, Security Interests in Personal Property. We noted other faculty in the room who must have been students of Gilmore's, just as he had been part of a generation trained by Corbin.

Before the 18th century, lawyers looked upon themselves-as they were looked upon by others-as being essentially plumbers or repairmen. By the end of the 18th century we had come to think of ourselves as philosophers-an upgrading of our status which the legal mind naturally found irresistible.

Gilmore then introduced the "Age of Discovery" by presenting its antecedents: prior to the second half of the 18th century there was no notion of a generalized theory of law. Blackstone had no predecessors. It was that half century-when "many remarkable minds set out, almost at the same time, to discover the laws of history, the laws of social and economic behavior, the laws, we might say, of law"-that encompassed America's construction of its own legal system. Having cut our political ties to England, conscious of our immense potential for wealth and power, self-critically committed to a legal system that made some kind of overall sense, we were a society poised for takeoff-a society capable of producing the Constitution.

That society confronted the task of selectively transplanting the English common law in a period of dizzying change (and overseas that law was experiencing similar stresses, evoking the creative, Mansfieldian approach to judging). To this task of constructing a ship while under sail were added the tensions of a potentially fragmenting federalism. The history of pre-Civil War American law is, in the main, an account of how law coped successfully, astonishingly-through the codification movement, through inspired judicial interpretation,e through Kent's Commentaries and Story's original and impressive treatises-with the structural forces of instability.

c. Thus, by the simple expedient of paying no attention whatever to the known meaning of the words chosen by the Constitutional draftsmen, the Court effectively federalized-nationalized-the law relating to all water borne transportation, an area of 
Summing up this period, Gilmore followed Llewellyn in finding its only counterpart in the great classical period of Roman Law, the third century A.D.f He ended the first lecture by saying, "The best definition of a golden age is, no doubt, that it is one which can never be repeated-or recaptured."

There was enthusiastic applause.

The following afternoon we returned to the lecture room. Well before the lecture was to begin, it became apparent that, with even the aisles already full, the lecture site would have to be moved. We decamped to the auditorium.

In a speech in 1963, Professor Gilmore had said,

No lawyer worthy of the name can ever be either truly a conservative or truly a radical: at one and the same time we must somehow devote ourselves to the preservation of tradition, which we do not greatly respect, and to the promotion of change, in which we do not greatly believe.s

Appropriately modest words for our chastened present; but for 1963? Yet we suspect that his oft-quoted epigram was not racy prescience. Rather it is a kind of gentleman's code, a statement of the perspective that structures the professional monologue of the Solitary, "fastidious, ironic, aristocratic."h If so, it is hardly paradoxical that the Storrs Lectures should adopt historical themes; the past, in the hands of the quick-witted, is just as unpredictable but not nearly so repetitious as the present.

Professor Gilmore spoke, that day, about "The Age of Faith." Discussing the period, roughly from the Civil War to World War I, of the "law's black night," he remarked that, paradoxically, American law had apparently achieved some of its greatest triumphs during that time. The major categories we use to study our legal system were reduced to order and certainty, indeed were invented, in this period.

Christopher Columbus Langdell, who in 1870 became the first Dean of the Harvard Law School, was the symbol of the age, and his one guiding idea the organizing principle of its energies. The idea was that law was "a science," and from this thesis several corollaries flowed. If legal truth is a species of scientific truth, then once discovered, it must necessarily endure. It follows as a methodological consequence that legal study will

economic activity which was of course even more vital in the period before the construction of railroads....

In an extended analysis of Swift v. Tyson, 41 U.S. (16 Pet.) 1 (1842), Professor Gilmorc demonstrated the method by which Justice Story promoted and substantially achieved national uniformity across a broad spectrum of the substantive law through a disingenuous yet quite creative rendering of a technical point of negotiable instruments law. That method advised courts not to take a narrow view of precedent, to look to the entire range of the available literature, scholarly as well as judicial, and to take into account the economic and social consequences of their decisions. "In short, Story was preaching what, a hundred years later, would be, somewhat barbarously, referred to as a policy-oriented approach to law."

f. See K. Llewellyn, The Common Law Tradition: Deciding Appeals 45 (1960).

g. Gilmore, The Truth About Harvard and Yale, Yale LAw REP., Winter 1963, at 9.

h. Spoken of Professor Gilmore by the late Herbert Packer on the presentation of the Coif Award in 1967. Quoted in Gunther, Herbert L. Packer, 26 STAN. L. REv. 1005, 1007 (1974). 
be devoted to the progressive simplification of formulae, and to an effort to reduce their number while increasing their explanatory power. The Langdellians thus sought, with considerable success, to design unifying theories which would embrace broad areas of the common law-theories which meant that the status of parties and the origin of their disputes were not to be taken into account.

Since hitherto the principal characteristic of American law had been its "chaotic diversity, its sensitivity to changing conditions, its fluidity," the American case law would support Langdell's theories only if it was ignored. The Langdellians did precisely that, citing a few English reports and a limited number of "right" cases in this country. At about the same time the West Publishing Company established the National Reporter System and the Langdellian revolution was complete: a precedent-based, largely nonstatutory system must have difficulty coping with such fecundity. The treatises of the period soon changed from simply identifying for the practitioner what the cases were, to stating the "correct rule," often in black letter text, and then justifying it in terms of broad generality. The supporting cases came in at the bottom of the page in typically factless string citations. Of the moving spirit of all this, Gilmore said, "Langdell seems to have been an essentially stupid man who, early in his life, hit on one great idea to which, thereafter, he clung with all the tenacity of genius."

We were sitting next to Professor Bittker and just before such lines were finished he would chuckle, always a bit more quickly, a little sooner than the rest. This both distracted and alarmed the young lady sitting next to us, who seemed unsure whether the Professor was very, very bright or had sneaked a look at the text. Of the speaker himself, we could notice a buoyant change since the first lecture. Professor Gilmore's extreme personal reticence seemed tempered by his appreciation of the institutional significance of the Lectures, and of the fact that he owned both a dramatic reading style and the face of Clemenceau. At any event, he turned next to the man whose biography he is presently writing.

"If Langdell gave the new jurisprudence its methodology, Holmes, more than anyone else, gave it its content." Holmes argued that the function of law is to channel private aggression in an orderly fashion. He wrote: "The first requirement of a sound body of law is that it should correspond with the actual feelings and demands of the community, whether right or wrong." In his radical and despairing pessimism, Holmes cut against the grain of most 19th century thought, which was characterized by an optimistic belief in the progressive amelioration of the human condition. Furthermore, he seems to have had a far more sophisticated idea about the nature of scientific inquiry than most 19th century social scientists, including the Langdellians. And, finally, he believed in the necessary instability and inconsistency of any given state of the law.

Despite all this, the lectures in which Holmes displayed these ideas to the world were enthusiastically received. Published the following year under the title The Common Law, they purported to be an historical survey

i. O.W. Holmes, JR., The Common Law 36 (M. Howe ed. 1963). 
of the development of a very few common law principles which had recurrently manifested themselves in the various subjects Holmes chose to deal with, principally tort and contract. The Langdellians, the believers in the one true rule of law, ignored Holmes's insights into the complex interplay between new materials drawn from life and old materials not quite absorbed from history, $\mathrm{i}$ but accepted Holmes's extremely general and equally parsimonious principles of liability.

Holmes's accomplishment was to make Langdellianism intellectually respectable. In the academic world, the success was complete. Concurrently, events of the period seemed to evoke opinions from the judiciary that unconsciously embodied Langdell's notions.

The post-Civil War judicial product starts from the assumption that law is a closed logical system. Judges do not make law; they merely declare the law, which, in some Platonic sense, already exists.k Seldom did judges make any attempt to explain the reasons for their own decisions; it was enough to say, "The rule which we apply has long been settled," citing numerous cases, without facts.

Langdell had nothing to do with shaping the new judicial approach. By his time we had put behind us the urgent problems which had concerned Kent and Story and had largely spent our energies in the Civil War. Even the pace of technological change seems to have slowed. Langdell was the first to sense the altered mood and give it theoretical expression. Such expression equally suited the economic movers and shapers of the day.

Referring, we hoped, to the economic theories of the early 20th century, Professor Gilmore reminded us:

There has always been a symbiotic relationship between the academic establishment, which provides the theories, and the economic establishment, which appreciates being told that the relentless pursuit of private gain is, in the last analysis, the best way of serving the public interest.

j. Langdellian jurisprudence led its adepts to the conclusion that law is a neat and tidy structure of interlocking logical propositions. Holmes began his first lecture ... with the celebrated epigram: "The life of the law has not been logic: it has been experience." The flashing thrust was apparently meant as, and understood by his audience as, a direct attack on Dean Langdell, who may indeed have been seated in the front row.

Gilmore, The Age of Antiquarius: On Legal History in a Time of Troubles, 39 U. CHI. L. REv. 475,480 (1972).

k. See W.H. Auden, Law Like Love, Collected Shorter Poems 1927-1957, at 154 (1966):

Law, says the judge as he looks down his nose,

Speaking clearly and most severely,

Law is as l've told you before,

Law is as you know I suppose,

Law is but let me explain it once more,

Law is the Law.

Yet law-abiding scholars write:

Law is neither wrong nor right,

Law is only crimes

Punished by places and by times,

Law is the clothes men wear

Anytime, anywhere,

Law is Good morning and Good night 


\section{But even the economists must have}

felt a grudging admiration for the lawyers who could see that the case of a working man bargaining with his corporate employer over wages and the case of a Vermont farmer dickering with a summer resident over the price of a cord of firewood could both be reduced to the paradigm of $A$ who voluntarily contracts with $B$.

As Gilmore had written in another context, "Never, I dare say, has any field of law appeared to be as perfectly structured, as free from any kind of fault or flaw, as the law of contracts in Williston's great treatise."l

Ending the second lecture, Gilmore responded to the ovation with a short bow.

The third lecture, on the last day in October, was again delivered in the auditorium. Gilmore's review of our legal past inexorably advanced on the present. The first two lectures had prepared us for an erudite review of America's grand designs and hopeful revolutions. Few expected what seemed to us the savage nihilism of the third lecture, which is here reprinted.

Twenty-five years ago, Professor Gilmore wrote of Karl Llewellyn in these pages that he "and his co-conspirators were right in everything they said about the law. They skillfully led us into the swamp. Their mistake was in being sure that they knew the way out of the swamp: they did not, at least we are still there."m And, Gilmore told us that afternoon, for tomorrow and tomorrow.

As we sat in the auditorium that afternoon, we had the feeling that ironies far beyond our comprehension, beyond even our guessing, continually pressed on Professor Gilmore.n Sometime ago, speaking of the law itself, he had written, "The more things change, the French proverb reminds us, the more they are the same: our gains, it may be, are illusory, but so are our losses."o

The Dean introduced him once again, an introduction acknowledged this time with a confident bow. Gilmore began in his customary rumble, his thick-lensed glasses reflecting the auditorium lights. His hands chopped the air with an offhanded impatience as he dashed hopes across our eager faces. When the third lecture was over, we rose and clapped and cheered.

P.G.B.

1. Gilmore, supra note j, at 481 .

m. Gilmore, Book Review, 60 YALE L.J. 1251, 1252 (1951).

n. Holmes, writing to Pollock, following the overwhelmingly positive reception to the former's appointment to the Supreme Court:

There have been stacks of notices of me all over the country.... They are so favorable that they make my nomination a popular stuccess but they have the flabbiness of American ignorance.... It makes one sick when he has broken his heart in trying to make every word living and real to see a lot of duffers, generally I think not even lawyers, talking with the sanctity of print in a way that at once discloses to the knowing eye that literally they don't know anything about it.

Letter from O.W. Holmes, Jr. to Sir Frederick Pollock, Feb. [Sept.?] 23, 1902, in HolmesPollock LetTERs 106 (M. Howe ed. 1961).

o. Gilmore, Legal Realism: Its Cause and Cure, 70 YALE L.J. 1037, 1048 (1961). 


\section{The Age of Anxiety}

It may well be that in the law Ages of Faith are of relatively brief duration. The pleasant and comforting myth of the law's internal consistency and external stability cannot, for long, sustain itself. The facts of life cannot, for long, be suppressed. Every Blackstone must have his Bentham; every Langdell must have his Llewellyn. The specifics of the breakdown, like the specifics of the original construction, are of course largely determined by the accidents of time and place.

The first sign that the heavenly city of the Langdellians was not for this world was, I suggest, the revival and apparent success of the American codification movement, which had not been heard from since before the Civil War. The codifiers had always taken commercial law as their preferred area of operation. In a period of twenty years beginning in the late 1890 's a series of uniform commercial statutes-of which the most important were the Negotiable Instruments Law $^{1}$ and the Uniform Sales Act $^{2}-$ was drafted, promulgated under the respectable auspices of the American Bar Association, and widely enacted throughout the country.

The presence of the American Bar Association as an approving sponsor makes clear that the codifying statutes were not the work of wildeyed revolutionaries. This was indeed a project dear to the heart of the orthodox establishment and it is symbolically fitting that Samuel Williston, the greatest Langdellian of them all, became the principal, we might even say the official, draftsman of the new statutes. But why should codification have suddenly become respectable?

Langdellian jurisprudence in its origins had been essentially an attempt to achieve unity of doctrine on the case-law level. Langdell and his contemporary followers were common lawyers to a man. The "one true rule of law" idea was of course almost immediately subjected to intolerable pressures by the mounting flood of case reports. The writers of the great treatises sought to keep the situation under

1. 5 UNIFORM LAws ANN. (1943), promulgated in 1896 by the National Conference of Commissioners on Uniform State Laws and subsequently adopted by every state; the Conference had been set up, as a sort of affiliate or subsidiary, by the American Bar Association. The Negotiable Instruments Law was the first project in which the Conference engaged.

2. 1 UNIFORM LAwS ANN. (1950), promulgated in 1906 by the National Conference of Commissioners on Uniform State Laws and subsequently adopted by 37 states; the Sales Act was the first of several statutes drafted for the Conference by Professor Samuel Williston of the Harvard Law School. 
control by carefully distinguishing between the relatively few correct cases (many of them English) and the great piles of trash which filled the bound volumes of the reports. However, another aspect of our late nineteenth century theory caused trouble at exactly this point. Judges were not supposed to make law; they merely followed precedents. So, what was a judge who took the stare decisis business seriously-as many did-to do when it turned out that the precedents in his state were, according to the learned gentlemen from Cambridge, wrong? The factual disunity of American case law from state to state may indeed have increased during the latter part of the nineteenth century as the nationalizing principle of Swift $v$. Tyson ${ }^{3}$ gradually lost its strength. The Swift $v$. Tyson device had not infrequently succeeded in producing nationally acceptable solutions to regionally controverted issues. As that device passed out of use American case law apparently faced a bleak future of rampant parochialism.

American interest in codification had no doubt been stimulated by then-recent English developments. The English, on their home turf, had of course paid not the slightest attention to Jeremy Bentham's strident manifestos calling for universal codification. The Benthamite idea apparently seemed more attractive when the question for decision became how best to secure the benefits of English civilizationincluding English law-for India. At all events the English undertook and patiently carried out the ambitious project of providing India with English-inspired codes. ${ }^{4}$ The success of the Indian project seems to have led to a hesitant beginning in codifying some of the more troublesome areas of domestic law with the Bills of Exchange Act $(1882)^{5}$ and the Sale of Goods Act (1893). ${ }^{6}$ Having gone so far, the English stopped and proceeded no further. Their two Victorian codifying statutes are still in effect. Proposals for further codification in this century ${ }^{7}$ have, after a flurry of initial publicity, been quietly abandoned.

The American codifiers-particularly after Williston's services had been enlisted-seem to have assumed that their principal function was to free judges, crippled by their devotion to stare decisis, from the fetters of aberrant precedents in unenlightened jurisdictions. Indeed

3. 41 U.S. (16 Pet.) 1 (1842).

4. See The Anglo-Indian Codes ix-xxviii (WV. Stokes ed. 1892).

5. $45 \& 46$ Vict., c.61.

6. $56 \& 57$ Vict., c.71.

7. See, e.g., Great Britain Law Commission, Law Commissions Act, 1965: First Programie of the Law Commission 6, 10 (1965). 
the only truly enlightened jurisdiction was what came to be referred to in moot court competitions at the Harvard Law School as the State of Ames. ${ }^{8}$ But with the law of Ames made available to all in statutory form, the true light could shine everywhere.

In truth, statutes like the Uniform Sales Act were not statutes at all. That is, they were not designed to provide rules for decision. Drafted in terms of loose and vague generality, what they were designed to provide was access to the prevailing academic wisdom. Thus the rules for decision in sales cases were to be found not in Professor Williston's Uniform Sales Act but in Professor Williston's treatise on the Law of Sales. This aspect of the codification was apparently generally understood. The courts-and, presumably, counsel-paid no attention at all to the Sales Act; they paid enormous attention to Professor Williston's treatise.

What we had was not so much a codification as a non-codificationa method of preserving the common law purged of all impurities. The apotheosis of the non-codification movement was reached a generation later with the Restatements of the 1920's and 1930's in which all the fundamental principles of the common law were reduced to authoritative statements printed in black-letter text. Not since the Digest of Justinian, which patiently collected for the use of sixth century Byzantium the wisdom of third century Roman jurisprudence, had there been anything like the American Restatements. ${ }^{10}$ Indeed the fate of both these extraordinary legal artifacts-Digest and Restatements-was the same: the hurricane continued to howl; the foundations continued to slip away; the wisdom of the past could not save.

We may take the provision in successive generations of, first, a statutory non-codification with the Uniform Sales Act and its successors and, next, a non-statutory non-codification with the Restatements as having obscurely reflected an almost instinctive realization on the part of the Langdellians-who enthusiastically supported both ventures -that things were not going as they were supposed to go-as, for a generation or more, they had seemed to be going.

Our dawning Age of Anxiety is perfectly symbolized by the mys-

8. James Barr Ames became Dean of the Harvard Law School in 1895, succeeding Langdell in that post.

9. S. Williston, The Law Governing Sales of Goods at Common Law and Under THE UNIFORM SALES ACT (1909).

10. The Restatements were produced by the American Law Institute. For a history of the Institute and its guiding force, William Draper Lewis, see Goodrich, The Story of the American Law Institute, 1951 WASH. U.L.Q. 283. The work of the Institute was financed by a grant from the Carnegie Corporation totalling nearly $\$ 2,500,000$. Id. at 288 . 
terious-almost mystical-figure of Benjamin Nathan Cardozo. Cardozo's father had been a corrupt lower court judge allied with the Tweed Ring in New York, who had suffered disgrace when Tweed's organization was broken up. The son apparently felt that his mission was to redeem his father's sins. Ascetic to an extraordinary degree in his personal tastes, he seems to have decided at an early age to renounce the pleasures and temptations of the world in favor of a life of intellectual meditation. The accounts of all those who knew him tell us of a man of an extraordinary and compelling personal charm as well as of great sweetness of character. By the universal testimony of his contemporaries Cardozo was a saint. ${ }^{11}$

Before his appointment to the Supreme Court of the United States in succession to Justice Holmes, Cardozo served for twenty years on the New York Court of Appeals and evidently dominated that great court, intellectually, throughout his tenure. Cardozo was a truly innovative-or, if you will, creative-judge, of a type which had long since gone out of fashion. In his opinions, however, he went to extraordinary lengths to hide his light under a bushel. The more innovative the decision to which he had persuaded his brethren on the court, the more his opinion strained to prove that absolutely no noveltynot the slightest departure from prior law-was involved. Since Cardozo was one of the best case lawyers who ever lived, the proof was invariably marshalled with a masterly elegance. It is not until the reader gets to the occasional angry dissent ${ }^{12}$ that he realizes that Cardozo had indeed been turning the law of New York upside down. During his twenty years Cardozo succeeded to an extraordinary degree in freeing up-and, of course, unsettling-the law of New York. It is true that he went about doing this in such an elliptical, convoluted, at times incomprehensible fashion that the less gifted lower court New York judges were frequently at a loss to understand what they were being told. ${ }^{13}$

11. See, e.g., B. Shientaf, The Seventy-Fifth Anniversary of the Birtil of Justice Benjamin N. Cardozo 1-2 (1945):

What words are there to describe the charm of an uncommon gentleness, of a singular simplicity that goes with spiritual distinction; to picture that candor, that rare integrity and purity of mind, that life of intellectual opulence and moral fervor? What words have we to adumbrate that exquisite grace of humility, that abiding serenity, that intense tenderness and compassion which flowed from having himself suffered?

12. See, e.g., Allegheny College v. National Chautauqua County Bank, 246 N.Y. 369, 379, 159 N.E. 173, 177 (1927) (Kellogg, J., dissenting); Jacob \& Youngs, Inc. v. Kent, 230 N.Y. 239, 245, 129 N.E. 889, 892 (1921) (McLaughlin, J., dissenting); MacPherson v. Buick Motor Co., 217 N.Y. 382, 395, 111 N.E. 1050, 1055 (1916) (Bartlett, C.J., dissenting).

13. See, e.g., Comfort v. McCorkle, 149 Misc. 826,268 N.Y.S. 192 (Sup. Ct. 1933). 
In 1920 Cardozo came to this School and delivered a series of Storrs lectures. I think it is fair to say that the two most celebrated books in the history of American jurisprudence are Holmes on The Common Law ${ }^{14}$ and Cardozo on The Nature of the Judicial Process. ${ }^{15}$ The two books, however, have nothing in common beyond the facts that nobody reads them and everybody praises them.

Cardozo's book, as a matter of strict fact, had almost no intellectual content whatever. He addressed himself to the problem of how a judge goes about deciding a case. In the great majority of all cases, he said, the outcome is foredoomed; the past has foreclosed the present. Only in an occasional case does the process of adjudication involve a creative act on the part of the judge. In such a case, Cardozo suggested, the judge may-indeed must-look to what he called the "methods" of philosophy, history, tradition and sociology. By the "method of sociology" he meant that the judge, at least in a situation where he found nothing else to guide him, was entitled to take into account the effect of his decision on social or economic conditions. Toward the end of his last lecture he introduced what one might call the theme of the anguish of judicial decision:

I was much troubled in spirit, in my first years on the bench, to find how trackless was the ocean on which I had embarked. I sought for certainty. I was oppressed and disheartened when I found that the quest for it was futile. I was trying to reach land, the solid land of fixed and settled rules, the paradise of a justice that would declare itself by tokens plainer and more commanding than its pale and glimmering reflections in my own vacillating mind and conscience.... As the years have gone by, and as I have reflected more and more upon the nature of the judicial process, I have become reconciled to the uncertainty, because I have grown to see it as inevitable. I have grown to see that the process in its highest reaches is not discovery, but creation; and that the doubts and misgivings, the hopes and fears, are part of the travail of mind, the pangs of death and the pangs of birth, in which principles that have served their day expire, and new principles are born. ${ }^{16}$

The thing that is hardest to understand about The Nature of the Judicial Process is the furor which its publication caused. Nothing can better illustrate the extraordinary hold which the Langdellian concept of law had acquired not only on the popular but on the legal

14. O.W. Holmes, Jr., The Common Law (1881) (M. Howe ed. 1963).

15. B. Cardozo, The Nature of the Judicial Process (1921).

16. Id. at $166 \cdot 67$. 
mind. Cardozo's hesitant confession that he-and other judges-were, on rare occasions, more than simple automata, that they made law instead of merely declaring it, was widely regarded as a legal version of hard-core pornography. By this unseemly indiscretion, it was suggested, Cardozo had forfeited any claim he might otherwise have had to be considered as a fit candidate for a seat on the Supreme Court of the United States. ${ }^{17}$ In time the furor abated and he did indeed take his seat on the Supreme Court without any visible sign of public indignation. But a less saintly man than Cardozo might, in 1920, have found himself running close to the reefs of impeachment.

Cardozo was, we might say, a revolutionary malgré lui who was affectionately attached to the structure which, imperceptibly, almost surreptitiously, he proceeded to subvert and destroy. There was, however, nothing affectionate, imperceptible or surreptitious about the procedures of the group, based mostly in the law schools, who shortly came to be known as the Legal Realists. They appeared to be, quite consciously, in favor of tearing everything down. On further analysis the case may prove to be that, just as Cardozo was a revolutionary malgré lui, the Realists were Langdellians malgré eux. In times of revolutionary change, it is often difficult to be sure who is on which side.

What the curious episode which came to be known as American Legal Realism was about has long been a puzzle not only to outsiders but to the participants. The late Karl Llewellyn, whom most people regarded as the leading Realist, insisted throughout his life that there had never been either a Realist "school" or a Realist "movement." Professor William Twining, one of the few English scholars who has ever devoted much time to the study of our transatlantic law-ways, seems to have concluded, in a recent book ${ }^{18}$ on Karl Llewellyn and the Realist Movement, that Legal Realism, if there was such a thing, was an exclusively American phenomenon which bore no relationship to any developments, past or present, in English legal history or in the history of any of the civil law systems. Indeed Professor Twining seems to suggest, by implication, that Legal Realism was, so to say, a playoff for the Ivy League championship with the combined faculties of the Columbia and Yale Law Schools taking the field against Harvard. I think there was more to it than that.

17. "[Cardozo] was aware that his conception of the judicial process was not the generally accepted one; and he had a slight hesitation about the publication of his lectures. With a touch of humor, he remarked, 'If I were to publish them I would be impeached." Corbin, Foreword to B. Cardozo, The Growth of the Law, at vi (1966).

18. W. Twining, KarL Llewelly and THE REALIST Movement (1973); I have reviewed Professor Twining's book in 22 AM. J. CoMp. Law 812 (1974). 
In a narrow sense, the so-called Realist controversy consisted of a series of articles which appeared in the law reviews during the 1930's and which, today, makes up as dreary a course of reading as you can hope to find anywhere. When Llewellyn denied that there had ever been a Realist school or movement, he was presumably referring to the law review controversy. It is surely true that, on the law review level, the issues at stake, which had never been clearly defined, became progressively more confused and more insubstantial as the debate went on. But neither Llewellyn nor anyone else was ever inclined to deny that a fundamental shift in American legal thought had taken place in the decades following World War I-a shift which the law review controversy, which was in itself inconsequential, served to underline or emphasize.

The one thing on which the academic theorists who emerged after World War I agreed was that the traditional or Langdellian way of achieving doctrinal unity on the level of case law or Restatement was absurd. However, in demonstrating the absurdity of the Langdellian thesis, the new generation of theorists used as their principal weapon one which Langdell himself had provided: the idea that the reported cases are the laboratory materials for our systematic or scientific study. In its Langdellian version that had meant that we were to study a few correct cases and disregard the rest. The post-Langdellians proposed to look at all the cases.

Arthur Corbin of this faculty may have been the first, as he was the greatest, of the post-Langdellian scholars. Corbin took no part in the Realist controversy and in any event his intellectual formation had been complete long before World War I. Llewellyn, who had studied under Corbin and been closely associated with him, regarded Corbin as his spiritual father in the law ${ }^{19}$ and most of the Realists treated Corbin with a respect which they showed to almost no other figure of the earlier generation.

Corbin counseled not only that we should study all the cases but also that we should study them not so much for their doctrinal statements as for what he liked to call their "operative facts." Furthermore, Corbin practiced what he preached, both in his teaching and in his writings which culminated in his great treatise on Contracts. ${ }^{20}$ In Corbin we no longer find the high level generalities supported by factless string citations which had characterized the Langdellian litera-

19. Indeed, Corbin's copy of Llewellyn's THE Common LAw Tradition is inscribed: "For Dad-in the hope that he will find it worthy of his great teaching.... Karl."

20. A. Corbin, Contracts (1950). 
ture, whose greatest achievement had been no doubt the other great treatise ${ }^{21}$ on Contracts written by Corbin's dear friend and lifelong opponent, Samuel Williston. In Corbin we find painstaking factual analyses of all the cases, even those of minor importance which are relegated to the footnotes. Indeed the practice of paying an almost obsessive regard to the facts of cases, while almost entirely disregarding their apparent doctrinal content, became after World War I, and has since remained, a principal characteristic of most American legal scholarship.

Unity of doctrine cannot survive that way of dealing with cases. At all events, in this country it did not survive. The process of disintegration is already evident in Corbin's own work. For example, he concluded that there was not, and never had been, such a thing as a, or the, doctrine of consideration. At various times and in various places and in a great variety of circumstances courts had imposed contractual liability. The only purpose of studying the field was to determine under what circumstances the liability had been imposed. There is no harm, Corbin cheerfully concluded, in using the word "consideration" which has been bequeathed to us by history. But, he added, if you want to use it, you should be aware that it means, and always has meant, many different and inconsistent things. ${ }^{22}$

Some of those who followed in Corbin's footsteps carried his teaching to the point of intellectual nihilism. Wesley Sturges, whom generations of students at this Law School revered as the greatest of teachers, was one. Early in his career Sturges published a few law review articles, which were of an almost unbelievably narrow scope and focus -for example, an elaborate study of the North Carolina case law on the nature of mortgages, ${ }^{23}$ a subject of no conceivable interest to Sturges or anyone else. The point of the study was to demonstrate that the North Carolina law of mortgages made no sense of any kind and could most charitably be described as a species of collective insanity on the march. At about the same time he put together a casebook for a new course which he called Credit Transactions: ${ }^{24}$ the

21. S. Williston, The LAw of Contracts (1920). See Corbin's tribute to Williston in Corbin, Samuel Williston, 76 HARv. L. REv. 1327 (1963).

22. 1 A. Corbin, Contracts $\$ 110$, at 494 (1963):

In each new case, the question for the court is "should this promise be enforced." Its problem is not merely to determine mechanically, or logically, whether it falls within Professor Wiseacre's statement of the doctrine of consideration or complies with some commonly repeated definition. This is not to say that the Professor's statement, or Restatement, or the learned judge's dictum, can be safely disregarded.

23. Comment, Validity of a Mortgage on Business Assets to Secure the Proprietor's Capital Contribution, 34 Yale L.J. 769 (1925).

24. W. Sturges, The Law of Credit Transactions (1930). 
casebook consisted principally of the most absurd cases and sequences of cases, along with the most idiotic law review comments, which he had been able to find. The law, as Wesley Sturges conceived it, bore a striking resemblance to the more despairing novels of Franz Kafka. Sturges himself had the courage of his bleak convictions. Ex nihilo nihil. He wrote almost nothing during the remainder of his long career. ${ }^{25}$ No one could match Sturges in his penetrating analysis of the most complex legal materials but he saw no point in playing children's games. I was his student and served under him while he was Dean of this School: he was a lonely, great and tragic figure.

Sturges was not in any sense typical of his generation. Most of his contemporaries thought of themselves as having broken with Langdellianism and all its ways but nevertheless accepted the basic tenet of Langdellian jurisprudence: the one true rule of law. Corbin, Sturges and others had demonstrated that there was no salvation in case law. But there might be other ways.

The idea that the facts of cases are all-important led in many minds to the conclusion that what we needed were more facts or better ways of getting at the relevant facts. It appeared that the social scientists, particularly the sociologists, had made great advances in techniques of what came to be called empirical research. But was not law itself a social science? And were not the techniques of empirical research quite as applicable to legal behavior as they were to any other kind of social behavior? Particularly among the self-proclaimed Realists the slogan "law is a social science" ${ }^{26}$ became an article of faith and young men who were beginning their careers were sternly advised to abandon the futile study of doctrine and to devote themselves instead to empirical studies.

Since the 1930's a great many empirical study projects on legal subjects have been undertaken, typically funded by lavish foundation grants and widely publicized at well-attended press conferences. The fate of most of these projects has been to wither on the vine without producing any fruit. It seems to be a fact of life that it is much more

25. Nothing, that is, on conventional law or legal theory. He became interested in arbitration as a promising alternative to judicial adjudication and published a comprehensive treatise on that subject, W. Sturges, A Treatise on Commercial Arbitrations AND AwarDs (1930).

26. See, e.g., Cook, The Logical and Legal Basis of the Conflict of Laws, 33 YALE L.J. 457,475 (1924) ("lawyers, like the physical scientists, are engaged in the study of objective physical phenomena.... As lawyers we are interested in knowing how certain officials of society-judges, legislators, and others-have behaved in the past, in order that we may make a prediction of their probable behavior in the future."); cf. Oliphant, $A$ Return to Stare Decisis, 14 A.B.A.J. 159 (1928) ("Not the judges" opinions, but which way they decide cases will be the dominant subject matter of any truly scientific study of law."). 
fun to think about or talk about doing empirical research than it is to do it. And even if you are able to employ armies of research assistants to gather all the facts there are, the gathered facts have a disappointing way of turning out not to mean anything beyond themselves.

The obvious alternative to a judicial solution of social and economic problems is a legislative solution. Courts can decide only the cases that happen to come before them and are in any case burdened by their own procedural limitations in trying to find out about the issues which the cases present. A legislature through its committees can analyze a problem in depth and cut through to a rational solution. If a continuing supervision or regulation is required, an administrative agency which will quickly develop its own expertise is the answer. In the first flush of enthusiasm doing all this seems like the merest child's play. Jeremy Bentham seems to have believed that running up a complete code for England, France or the United States ${ }^{27}$ would be as simple as rolling off a log. In this country in the twentieth century we seem to have had more than our fair share of Jeremy Benthams.

The so-called progressive movement which had flourished at about the time of World War I had put great stress both on individual government service as a way of life and on the role of government in prescribing for our social ills. States which came under the influence of progressive ideology-Wisconsin under the Lafollettes, Pennsylvania under Gifford Pinchot-were hailed as laboratories for experiments in social progress. The possibility that the experiments might fail seems never to have been seriously considered. With the coming of the New Deal the opportunity for experimentation on a much grander scale was at hand.

Many of the academic Realists, gladly forsaking their lives of scholarly research, enlisted for the duration and came to be numbered among the leading movers and shakers of the New Deal period. They drafted statutes by the gross and set up administrative agencies by the score. Having created a new world, they rested and hallowed it. Oddly, the problems did not go away and Utopia was as remote as ever. But their statutes have remained on the books and their administrative agencies in being. What to do about these mouldering statutes and elderly agencies will presently become an urgent problem of law reform.

The enthusiasm for legislative solutions was by no means restricted to federal legislation in the public sector. The American Law Institute,

27. See J. Bentham, Justice and Codification Petitions (1829). 
after having finished restating the common law, drifted, apparently almost without knowing what it was doing, into what became the massive codification project called the Uniform Commercial Code.28 With appropriate symbolism, Karl Llewellyn, the proto-Realist, became the architect of the Code and its principal draftsman. Llewellyn, who was much less of a revolutionary than he was thought to be, seems to have preferred a loose, open-ended style of drafting. If Llewellyn had had his way, the Code would have turned out to be another statutory non-codification or Restatement. In large part, however, he was overridden and outvoted by the proponents-mostly practitioners-of a much tighter drafting style. Llewellyn had envisioned a statute which would set general guidelines of policy and not much more. The practitioners who participated in the project wanted a statute which gave specific answers to specific problems and that approach largely prevailed. In the detail and rigid precision of much of its drafting, the Code will cause us all much grief.

While the legal scholars were becoming social scientists and the legal activists were drafting statutes and administering agencies, what were the judges doing? The conventional wisdom of the 1930's was that the judges had had their day, which would not come again. The Realists had stripped them of their trappings of black-robed infallibility and revealed them to be fallible human beings whose decisions were motivated much more by irrational prejudice than by rules of law. Furthermore our law, state and federal, was in the process of being reduced to statutory form with most of the significant continuing problems being committed to the expertise of administrative agencies. The judicial role was bound to become progressively more modest, more mechanical, more unimportant. What happened, as is frequently the case, was the opposite of what the conventional wisdom assumed.

The judicial activism of the Warren Court in areas of public or constitutional law has for a long time been a matter of public praise or blame. The truth is, I suggest, that the birth, or rebirth, of judicial activism considerably antedated the formation of the Warren Court and has been quite as much a factor to be reckoned with in the state courts as in the federal courts and in areas of private law as in areas of public law. Present prospects are that this surge of activism will continue, no matter who may sit on the Supreme Court of the United States or on our less august tribunals.

In an earlier lecture I suggested that the post-Civil War judges and

28. I was associated with the Code project, as a member of the drafting staff, from 1946 on. The following comments are based on my memory of what took place. 
theorists seemed, on the obscure level of instinct, to be working toward the same goals. The patterns which the theorists provided and the results which the judges arrived at seemed to be in perfect harmony. Among the striking features of our post-Civil War jurisprudence were its fondness for abstraction and for building unitary theories as well as its insistence on restricting both liability and damages.

No doubt the obscure correspondence between theory and practice holds true in any period. It has surely been true in this century that the reforms which the professors called for in their law review articles were already being provided, or had been provided, by the judges, without anybody having noticed what had happened. The universal abstractions faded, the unitary theories disappeared, the range of liability became wider and wider and plaintiffs' damages flourished like the green bay tree.29

The rebirth of judicial activism has gone hand in hand with a rebirth of the federalizing or nationalizing principle. In 1938 a unanimous Supreme Court declared that the federal law doctrine of Swift $v$. Tyson ${ }^{30}$ was, and always had been, unconstitutional. ${ }^{31}$ The Swift $v$. Tyson device, which had over a long period been of great service, had, for reasons which have been discussed, ceased to work in this century. No doubt the only sensible course was to get rid of it, as the Supreme Court did. But, having scrapped the machine that no longer worked, the Court immediately set about providing a substitute that would work.

Even at the time the Erie case was decided, a prescient observer might have commented that the case's apparent meaning could hardly be taken as its true meaning. It was unlikely to the point of impossibility that control over the development of the substantive law was to be returned to the several states just at the time when the powers and presence of the federal government in all areas of our national life had reached a point previously unknown in our history. And that proposition, which was clearly enough true in the years preceding World War II, had long since passed the point of no return by the time we had come to the end of the war period.

The post-Erie federalization of the law was not established all at once by the fiat of a single great case. Rather, the federalizing principle expressed itself in a variety of ways as the courts reacted to the

29. See generally G. Gilmore, The Death of Contract (1974); Restatement (Second) of Contracts $\$ 90$, comments d, e, at 217-19 (1973).

30. 41 U.S. (16 Pet.) 1 (1842).

31. Erie R.R. v. Tompkins, 304 U.S. 64 (1938). 
reality of ever-increasing federal power ${ }^{32}$ Insofar as a principle ever emerged, it was that the presence of any kind of federal interest in a case was enough to support the conclusion that decision should be governed by federal law rather than by the law of any state.

\section{Conclusion}

As we pause to observe our sesquicentennial, what can we make of our hundred and fifty years of law? And is there anything relevant that we can say about the next hundred and fifty years-or even about the next fifty (since it is at least arguable that the rhythm of the law is measured in fifty-year cycles)?

The principal thing that we can learn from our study of the past is that we cannot predict the future. At the beginning of these lectures I referred to the great eighteenth century hypothesis which led to the invention not only of law or jurisprudence but also of the whole range of the social sciences. That hypothesis was that there were observable regularities in social behavior or in societal development. Once the assumed regularities or developmental sequences had been identified, isolated for study and accurately described, it should follow that the future course of events could be predicted. With the power to predict would of course go the power to control. Once the forces at work are known and understood, they can be channeled or harnessed to serve the wants and needs not necessarily of mankind at large but at least of those who are in a position to manipulate them.

We have never had to face up to that frightening possibility for the excellent reason that no historian, social scientist or legal theorist has ever succeeded in predicting anything. That is, the great hypothesis, after two hundred years of anguished labor, has produced nothing. The assumed regularities have never been discovered; the formulations of each generation have regularly collapsed when the realities of the following generation have become known. Nevertheless the dream dies hard. Each generation of investigators, recognizing the errors of the past, has taken up the struggle anew in the conviction that the cause of past failure lay in inadequate methodology and in the optimistic belief that with more refined methods the trick will finally be pulled off. The historians have ransacked the archives. The sociologists have perfected increasingly complicated techniques for

32. See Friendly, In Praise of Erie-And of the New Federal Common Law, 39 N.Y.U.L. REv. 383 (1964). 
carrying out their empirical research and have surely succeeded in finding out more and more about less and less. At the present time only the economists, who for two hundred years have seen their theories regularly run off the rails, seem ready to give up and go out of business.

Let us assume that the lesson of the past two centuries is that the great hypothesis was fundamentally in error. The truth is that there are no observable regularities in the course of human events. The truth is that we cannot predict anything. The truth is that it is not possible to make scientific statements about history, sociology, economics-or law.

The "law is a science" analogy has conditioned our thinking for a long time. It has not only set our goals for us but has dictated our methods of study and research. It has told us not only what we were looking for but how the search was to be conducted. If we can rid ourselves-or if our successors can rid themselves-of the illusion that law is some kind of science-natural, social or pseudo-and of the twin illusion that the purpose of law study is prediction, that will be a clear gain for the future of our law.

It is also an illusion to think that the golden age will ever come again. In our history the golden age of the law was in the period before the Civil War. That may well have been a unique response to a unique historical situation. It cannot be an everyday occurrence that a society already in an advanced stage of its own developmentliterate, prosperous, buoyant, even euphoric-undertakes to create its own system of law, borrowing from a respected foreign system but feeling in no way constrained by any particular rule or precept of that system. We will, for obvious reasons, never find ourselves in that situation again.

The extraordinary achievement of our first half century of law may well have contributed to the excesses of the following half century. In the 1870 's it must have been tempting to conclude that since, through law, much had been achieved, it followed that, through law, everything could be achieved-including the ultimate goals of scientific prediction and scientific control of the future course of our society. In the 1970's we look back on an unpleasant half century which has been largely devoted to destroying the illusions which had commended themselves to the men of the 1870's. It may not be unreasonable to assume that, after our half century of demolition work, we are in for a half century of rebuilding-perhaps with Mr. Ralph Nader replacing Dean Langdell at the controls. 
One of the problems that our rebuilders-whoever they may prove to be-will have to deal with is how to go on living with a largely codified law after the codifying statutes have themselves passed out of date. It appears to be a fact of legislative life that it is much easier to get a statute enacted in the first place than it is to get the statute periodically revised so that it will make sense in the light of changed conditions. And it is obviously true that the more tightly the statute was drafted originally the more difficult it becomes to adjust the statute to changing conditions without legislative revision.

Over a fairly long period of time the problem of obsolescent statutes will solve itself. No statutory draftsman has a crystal ball in which he can read the future. The best he can do is to try to make some kind of sense out of the past. A well-drafted statute will usually deal sensibly with the issues which have come into litigation during the twenty or twenty-five years which preceded the drafting. However, the focus of litigation has a way of shifting unexpectedly and unpredictably. New issues, which no one ever dreamed of, present themselves for decision. With luck, the case will be that the old statute will turn out to have nothing to say one way or the other about the new issues, which can then be decided on their own merits. As that process continues the old statute gradually becomes irrelevant and is, so to say, reabsorbed within the mainstream of the common law. But that takes a long time.

The most difficult period in the life of a statute-as in the life of a human being-is what we call middle age. The statute is, admittedly, no longer what it once was but there is life in the old dog yet. An occasional subsection still has its teeth and subparagraph (3)(b) may burn with a gem-like flame. Beginning in the 1930's we went through our youthful orgy of statute drafting. Over the next little while we shall be passing through our statutory middle age.

The rebirth of judicial activism will help us through this difficult period. Statutory language-like any other kind of language-always, or almost always, presents alternative possibilities of construction. There will, however, be cases where even the most disingenuous construction will not save the day. The wisdom of the past fifty years has been that, in such a situation, a court must bow to the legislative command, however absurd, however unjust, however wicked. I should not be surprised to see this piece of wisdom rewritten over the next fifty years. We may well come to believe that the reformulation of an obsolete statutory provision is quite as legitimately within the judicial function as the reformulation of an obsolete common law rule. 
When the problem is one of freeing up a rule of state law, decisional or statutory, the new federalism will of course simplify matters. Fashioning a "federal rule" where none previously existed mostly involves either choosing between conflicting rules which have been previously formulated or adapting an obsolescent rule to serve a new purpose. The increasing localization of many types of litigation in the federal courts-such as bankruptcy proceedings, for one example -frequently presents the situation where the apparently applicable rule of state law is one which the state court has not passed on for a generation or more. That situation caused a good deal of trouble and frustration in the immediate aftermath of the Erie case when, for a few years, the apparent meaning of Erie was taken to be its true meaning. But we have now reached the point where no federal judge who has the slightest flair for his craft has to be concerned with even the most horrifying clinker which he may pick up from the nineteenth century dust heap.

The problem of freeing up the federal law is both more difficult conceptually and more serious practically. It is difficult to the point of impossibility to draw the attention of a crisis-ridden Congress to areas of law reform which, although urgent, have not erupted in political controversy. It is rapidly becoming equally difficult to draw the attention of a crisis-ridden Supreme Court, which is able to decide only a small fraction of the cases which are submitted to it, to the desirability of reconsidering its own ill-considered or obsolete holdings. Perhaps the inferior federal courts will have to experiment with the novel idea that, in case of need, they should not follow or consider themselves bound by obsolete Supreme Court cases. ${ }^{33}$

We have always turned to the federalizing-or nationalizing-principle as the solution to the obvious dangers of a fragmentation of the law on the state level. It may well be that the next period will see the emergence of what might be called an internationalizing principle. The global threats of environmental pollution and of long-term shortages of essential raw materials including food are only the most obvious examples of pressing problems which simply cannot be handled on the national level. Other problems of the same sort will be revealed as we proceed. The solutions, if there are to be solutions, will have to be international solutions-peacefully negotiated or imposed by force. One of the incidental by-products of an internationalizing approach to intractable problems would no doubt be the at first imperceptible spread of the idea that the internationalizing principle

33. See Note, Lower Court Disavowal of Supreme Court Precedent, 60 VA. L. Rev. 494 (1974). 
could be used to free up the increasingly arthritic joints of our middleaged federal statutes and of the rules of our decisional law which have qualified for senior citizen status.

If indeed we turn from nationalism to internationalism as a principle of organizing our law, I hope that we-or our successors-will be able to avoid the Jeremy Bentham syndrome. The Benthamite disease consists, essentially, in the belief that there is only one more river to Jordan and that, once we have crossed the river, everything will be tickety-boo. A system of law, internationally organized, will be no more stable, no more predictable, no more just-or for that matter, unjust-than systems of law nationally organized.

Law is always an instinctive response to disorder, never a reasoned approach to the quite different problem of achieving order. For ten years or so after World War II the slogan World Peace through World Law was one which appealed to many men of good will. That always seemed to me to be a case of putting the cart before the horse. Conceivably, we might get World Law through World Peace but not the other way around. And if we did achieve World Law through World Peace-the Romans, you will remember, are said to have made a desert and called it peace-there is no reason to believe that we would be any better off, legally speaking, than we are now.

In an earlier lecture I commented on the extraordinary degree of popular enthusiasm for the idea of law during the strange, dead period which followed the Civil War, which I have called our Age of Faith. Justice Holmes, before his death, was translated into a folk-hero, much to his own amusement and secret pleasure. Lawyers, naturally enough, responded warmly to their new-found position in the public esteem and proceeded to assure their admirers that the law and its acolytes were indeed worthy of an unbounded respect, a mystical adoration. In one of the great advertising campaigns of the century, the idea of law-of what came to be called the rule of law-was ridiculously oversold, which led to great confusion in the public mind when it later became clear that ours was a government not of laws but of men and that justice under law was notably unequal.

Law reflects but in no sense determines the moral worth of a society. A reasonably just society will reflect its values in a reasonably just law. The better the society, the less law there will be. In Heaven there will be no law and the lion will lie down with the lamb. An unjust society will reflect its values in an unjust law. The worse the society, the more law there will be. In Hell there will be. nothing but law, and due process will be meticulously observed. 